\title{
APLIKASI KINCIR ANGIN SAVONIUS UNTUK PENGAIRAN TAMBAK GARAM
}

\author{
Zilman Syarif ${ }^{1}$, Duma Pabiban²
}

\begin{abstract}
Abstrak :
Sentra produksi garam di Provinsi NTT adalah di Kabupaten Kupang, Nagekeo dan Ende. Tahun 2011 melalui program PUGAR, Program ini untuk mendukung industri garam yang menargetkan pada 2014 mencapai 1.200.000 ton/tahun dan ada modal penguatan modal (BLM Pugar). Proses pembuatan garam secara umum dilakukan melalui proses penguapan oleh sinar matahari pada lahan tambak garam.

Pada kelompok petani tambak garam, untuk mengairi lahan dengan air laut biasanya memakai motor pompa air yang menggunakan bahan bakar bensin, sedangkan lama waktu mengairi 1 ha diperlukan waktu \pm 3 jam untuk ketinggian air $10 \mathrm{~cm}$ dengan menghabiskan bahan bakar \pm 3 liter. Bahan bakar bensin dibeli dengan harga Rp 6.000,- per botol (isi bersih dari botol $900 \mathrm{ml}$ ) sehingga diperlukan \pm 4 botol bensin dengan demikian biaya pembelian bahan bakar bensin adalah Rp. 24.000,- untuk satu kali pengairan lahan. Pengairan air asin ke lahan biasa dilakukan setiap 3 - 4 hari tergantung dari cuaca (sinar matahari).

Teknologi tepat guna yang dipilih adalah menggunakan kincir angin type Savonius, kincir angin yang akan berputar terus bilamana ada aliran angin yang menyapu sudu-sudu kincir angin setengah silinder dari berbagai arah, gaya putaran porosnya dapat langsung digunakan atau dapat juga dikopel dengan mekanik (gier) dengan langkah sistem pompa pengambil air untuk mengambil air dari lahan penampungan untuk dialirkan ke lahan tambak garam.

Hasil yang diperoleh setelah pompa terpasang dapat diketahui bahwa pompa dapat bekerja dengan baik sesuai harapan yaitu diperoleh 50 - 70 putaran kincir angin pada kecepatan angin normal 3 sampai dengan 7 km/menit sehingga diperoleh daya isap pompa dalam satu menit antara 10-14 kali, dapat mengalirkan air ke tambak garam dengan kemampuan setara dengan 19,625 liter sampai dengan 27,475 Liter air/menit.
\end{abstract}

Kata-kata Kunci : Tambak Garam, Kincir Angin Savonius, Pompa Air.

\section{PENDAHULUAN}

Nusa Tenggara Timur dikenal karena memiliki asset pariwisata nasional berupa danau tiga warna yang terletak di Flores. Luas Daerah Tingkat I Nusa Tenggara Timur seluruhnya ku- rang lebih 47.389, 2 kmî. Iklim daerah ini pada umumnya kering dengan penyebaran curah hujan tidak merata.

Secara geografis Propinsi Nusa Tenggara Timur terletak di sebelah selatan Indonesia antara $9^{\circ}-12^{\circ}$ lintang selatan dan $118^{\circ}-125^{\circ}$ bujur timur, merupakan daerah kepulauan dengan jumlah pulau sekitar 566 buah dan memiliki garis pantai yang cukup panjang, terdapat hamparan tanah di pesisir pantai dengan luas keseluruhan mencapai 9.680 hektar yang terdapat di Kabupaten Kupang 7.000 ha, Kabupaten Ngada 2.000 ha, Kabupaten Ende 500 ha, Kabupaten Timor Tengah Utara 100 ha, Kabupaten Rote Ndao 60 ha, dan Kabupaten 
Sumba Timur 20 ha. Musim panas di Propinsi NTT biasanya berlangsung lama $\mathrm{n}$ kecepatan angin rata-rata $40 \mathrm{~km} / \mathrm{jam}$. Sementara kelembaban udara sekitar $60^{\circ}$ nisbi, tingkat kepekatan awal air laut bersih sebesar $3^{\circ} \mathrm{Be}$ (derajat Baume), sedangkan tekstur tanahnya padat dan kedap air sehingga resapan airnya sangat kecil. Melihat gambaran kondisi geografis seperti tersebut diatas maka Propinsi NTT memiliki potensi yang besar sebagai salah satu produsen industri garam nasional. (Nahib, 2012)

Program nasional swasembada garam nasional yang dimulai tahun 2009 dan Program Pemberdayaan Usaha Garam Rakyat (PUGAR) diharapkan mampu mempercepat tercapainya bebas impor garam pada tahun 2014. Untuk mencapai itu tentunya diperlukan dukungan informasi geospasial.

Sentra produksi garam di Provinsi NTT adalah di Kabupaten Kupang, Nagekeo dan Ende. Tahun 2011 melalui program PUGAR, Program ini untuk mendukung industri garam yang menargetkan pada 2014 mencapai 1.200.000 ton/tahun dan ada modal penguatan modal (BLM Pugar). Pengusahaan garam di Kabupaten Kupang belum adanya sentuhan teknologi. Proses pembuatan garam secara umum dilakukan melalui proses pembuatan garam pada lahan tambak. (Tempo, 2012).

Tetapi masih ada juga yang membuat garam secara tradisional, seperti yang dilakukan di Desa Pitai, Pantai Beringin dan Desa Pariti (Kecamatan Sulamu). Pengolahan atau pembuatan garam masih menggunakan cara sederhana (tradisional/tidak menggunakan tambak). Hal yang sama juga dilakukan oleh para nelayan garam di Desa Obelo di Kecamatan Kupang Tengah. Untuk Desa Oli O Kelurahan Merdeka Kecamatan Kupang Timur kelompok usaha garam di desa tersebut menggunakan tambak untuk memproduksi garam.

Pada Desa Oli O terdapat 10 kelompok usaha garam tambak, salah satunya adalah Kelompok Usaha Garam Mutiara Pantai dibentuk sejak tanggal 14 Juni 2012 dan Kelompok Usaha Garam Kharisma 10 Juni 2012 ke dua kelompok ini beranggotakan terdiri dari 5 sampai dengan 7 orang, kelompok ini telah mendapat pengesahan usaha dari Lurah Merdeka dengan surat keputusan nomor 520/ 05/Tahun 2013, tertanggal 08 Pebruari 2013 atas nama Lurah Merdeka untuk Kelompok Usaha Garam Kharisma dan surat keputusan nomor 520/04/Tahun 2013, tertanggal 08 Pebruari 2013 untuk Kelompok Usaha Garam Mutiara Pantai (SK Terlampir).

Dari hasil survey awal dapat di informasikan bahwa kedua kelompok tersebut (Kharisma dan Mutiara Pantai) masing-masing anggota minimal memiliki 1 ha lahan tambak garam. Untuk mengairi lahan kelompok memiliki motor pompa air yang menggunakan bahan bakar bensin, sedangkan lama waktu mengairi 1 ha diperlukan waktu \pm 3 jam untuk ketinggian air $10 \mathrm{~cm}$ dengan menghabiskan bahan bakar \pm 3 liter. Bahan bakar bensin dibeli dengan harga Rp 6.000,- per botol (isi bersih dari botol 900 ml) karena jauh dari tempat penjualan bensin umum (SPBU) sehingga diperlukan \pm 4 botol bensin dengan demikian biaya pembelian bahan bakar bensin adalah Rp. 24.000,- untuk satu kali pengairan lahan. Pompa digunakan secara bergantian diantara sesama anggota kelompok dengan biaya pembelian bahan bakar dibebankan kepada anggota yang menggunakan pompa saat itu. Pengairan air asin ke lahan biasa dilakukan setiap 3-4 hari tergantung dari cuaca (sinar matahari).

Dari satu kali musim produksi memerlukan waktu kurang lebih 6 bulan dan dapat menghasilkan kurang lebih 1.000 karung garam batu (garam kasar). Garam tersebut dijual seharga 50.000 rupiah per karung kepada pedagang pengolah karena, garam batu tersebut masih harus diperoses untuk menghasilkan garam bersih agar dapat dikonsumsi, setelah itu baru dapat dijual ke konsumen dengan harga 5.000 rupiah per kilogram.

Berdasarkan analisis situasi yang telah diuraikan diatas maka dapat diketahui bahwa Kelompok Usaha Garam Tambak Kharisma dan Mutiara Pantai di Desa Oli O terdapat beberapa permasalahan antara lain. 


\section{1 | Jurnal Ilmiah FLASH $\quad$ Volume 3 Nomor 2 Desember 2017}

Sistem pengairan untuk tambak garam menggunakan mesin pompa dengan biaya $\mathrm{Rp}$. 24.000,- untuk satu kali pengisian lahan tambak garam dengan luas lahan 1 ha untuk ketinggian air asin $10 \mathrm{~cm}$, lama pengisian \pm 3 jam.

Belum adanya teknologi tepat guna (sederhana) yang dapat meringankan biaya pengairan lahan tambak garam seperti pompa air dengan menggunakan pembangkit tenaga terbarukan misalnya tenaga angin yang dapat menggerakkan kincir angin yang terhubung pada mekanik pompa air untuk memompa air, mengingat lokasi dari tambak garam yang berada di pesisir pantai yang mana potensi angin sangat menungkinkan untuk dibuat kincir angin.

Dari 2 permasalahan tersebut di atas maka yang menjadi masalah utama adalah sistem pengairan lahan tambak garam yang masih memerlukan biaya sehingga mengakibatkan pendapatan menjadi berkurang.

Hubungan antara pengusul dan mitra dalam mengambil keputusan untuk menentukan pemecahan masalah tersebut diatas adalah dengan membuat sebuah kincir angin yang dapat menggantikan pompa air dengan bahan bakar bensin. Untuk diketahui kincir angin sebagai percontohan akan di tempatkan pada lahan tambak garam milik salah satu anggota kelompok sesuai dengan persetujuan bersama, akan tetapi kincir angin tersebut dirancang untuk dapat dipindah-pindahkan.

Target dan luaran yang akan dihasilkan dari setiap tahap rencana kegiatan adalah:

Pada kegiatan 1. Target luarannya adalah dihasilkannya satu unit model kincir angin type Savonius yang dapat memompa air asin dari penampungan ke lahan tambak garam yang akan diairi.

Pada kegiatan ke 2. Diperoleh data dari kinerja kincir angin type Savonius yang telah dihasilkan pada kegiatan 1 .

\section{METODE PELAKSANAAN}

Solusi yang perlu dilakukan untuk mengatasi permasalahan tersebut adalah diperlukannya teknologi tepat guna untuk pengadaan air bersih, dengan memanfaatkan energi terbarukan yaitu energi yang dapat diperbaharui dan apabila dikelola dengan baik, sumber daya itu tidak akan habis salah satunya yaitu tenaga angin yang dapat dimanfaatkan untuk menggerakkan kincir angin selanjutnya memompa air asin untuk digunakan mengairi lahan tambak garam.

Teknologi tepat guna yang dipilih dan disepakati adalah menggunakan kincir angin type Savonius, kincir angin ini termasuk dalam kincir angin sumbu vertikal yang akan berputar terus bilamana ada aliran angin yang menyapu sudu-sudu kincir angin setengah silinder dari berbagai arah porosnya dapat langsung dikopel dengan mekanik (gier) dengan langkah sistem pompa pengambil air untuk mengambil air dari lahan penampungan untuk dialirkan ke lahan tambak garam.

Beberapa keunggulan kincir angin savonius antara lain sederhana dan murah dalam konstruksi serta dapat menerima angin dari berbagai arah sehingga tidak diperlukan pengarah angin, memiliki putaran yang kuat serta dapat beroperasi pada pututaran angin yang rendah.

Metode yang dilakukan dalam mendukung rencana kegiatan tersebut terbagi atas 2 (dua) tahap :

Rencana kegiatan I (pembuatan kincir angin type Savonius)

a. Sebelum dilakukan pembuatan kincir angin dilakukan penyuluhan pada kelompok tentang cara pembuatan kincir angin dengan type Savonius dan pengoperasian serta pemeliharaanya.

b.Membuat kincir angin sesuai perencanaan dengan melibatkan semua anggota kelompok dengan kerja bersama-sama.

Rencana kegiatan 2 (penempatan kincir angin) a. Setelah kincir angin selesai dibuat dan di uji coba langkah berikutnya adalah merakitnya 
pada lokasi yang telah disepakati yaitu pada lahan tambak garam milik salah seorang anggota kelompok yang telah disetujui bersama, selanjutnya dapat dipindahkan pada lahan yang lain.

b.Mengamati kinerja dari kincir angin selama waktu yang bibutuhkan dengan melakukan pendataan untuk memperoleh informasi dengan melakukan pengukuran seperti berapa meter kubik air yang dihasilkan dalam satu jam, sehari, perminggu dan seterusnya.

\section{HASIL DAN PEMBAHASAN}

Hasil yang telah dicapai dalam kegiatan pengabdian masyarakat ini adalah;

1.Kegiatan survey awal dan persiapan pelaksanaan pengabdian. Kegiatan berupa kegiatan perijinan dan persiapan pelaksanaan, pada kegiatan ini sudah dilakukan pertemuan awal dengan kelompok petani garam. Dari hasil kegiatan wawancara dan diskusi awal diketahui bahwa petani garam mengalami kesulitan dalam mengairi ladang garamnya yaitu memerlukan biaya ekstra karena menggunakan mesin pompa air yang menggunakan bahan bakar bensin. Para petani garam berharap adanya teknologi tepat guna yang dapat menghemat anggaran pengeluaran tersebut misalnya kincir angin yang dapat bekerja terus menerus sehingga dapat menekan biaya pengeluaran oleh karena itu kegiatan pengabdian ini kemudian dirancang dan dikemas dengan membuat jadwal Faktual Pelaksanaan Kegiatan (time scadule) untuk pelaksanaan kegiatan, diskusi, peminjaman laboratorium kerja bangku dan pembelian diperlukan beberapa bahan dan peralatan untuk mengawali kegiatan.

2.Selanjutnya membuat rancangan dari kincir angin dengan tipe Savonius seperti yang telah disepakati dalam target luaran yaitu menghasilkan satu unit model kincir angin type Savonius yang dapat memompa air asin dari penampungan ke lahan tambak garam yang akan diairi. Gambar-gambar dari rancangan tersebut dapat dilihat pada rancangan di bawah ini;

Gbr 1. Rancangan Kincir Angin

Gbr 2. Rancangan Detil A dan B

3.Pembuatan kincir savonius dan pemasangan pada rangkanya. Kincir angin yang telah selesai dibuat dipasangkan pada rangkanya dan dilakukan pengujian agar kincir angin dapat bebas berputar dan tidak ada bagian yang tertahan.

4.Perakitan bantalan kincir angin serta pembuatan dan pemasangan pompa. Setelah kincir angin telah terpasang pada rangkanya selanjutnya dipasang pompa. 
Gbr. 3. Lahan yang belum dipasang Kincir Angin

Gbr. 4. Kincir Angin yang telah dipasang di Lahan

\section{Monitoring dan evaluasi}

Tahap ahkir dari pengabdian ini yaitu melakukan monitoring dan evaluasi dari kinerja kincir di lokasi, dari pengamatan selama 2 (dua minggu) dapat diketahui bahwa kincir dapat bekerja sesuai dengan yang di harapkan dengan perolehan data sebagai berikut : pada kecepatan angin normal 5 sampai dengan $10 \mathrm{~km} / \mathrm{jam}$ (Badan metreologi dan Giofisika Kupang) diperoleh putaran kincir rata 50 sampai 70 putaran per menit, air yang berhasil dipompakan rata-rata sebanyak $2000 \mathrm{ml}$ atau 2 Liter maka dalam 1 jam kerja pompa dapat memompa air sebanyak 1.200 Liter air yang dialirkan secara terus menerus.
Hasil yang diperoleh ini sesuai dengan teori matematis praktis yang diterapkan sebagai berikut; perbandingan geer mekanik adalah 5 : 1 artinya 5 kali putaran kincir maka terdapat 1 (satu) kali putaran geer untuk mengangkat pompa (mengisap air). Dengan tinggi ( $\mathrm{t}$ ) isap $10 \mathrm{~cm}$ dan jari-jari (r) selinder pompa $2,5 \mathrm{~cm}$, dengan menghitung menggunakan rumus Volume selinder , maka diperoleh volume selinder $196,25 \mathrm{~m}^{3}$ atau 1,9625 liter untuk satu kali isapan pompa. Dari hasil monitoring diperoleh $50-70$ putaran kincir angin dengan kecepatan angin normal antara 3 sampai dengan $7 \mathrm{~km} /$ menit sehingga diperoleh daya isap pompa dalam satu menit antara 10 14 kali, hal ini setara dengan 19,625 liter sampai dengan 27,475 Liter air/menit.

\section{KESIMPULAN}

Kegiatan pengabdian sudah dilakukan dimulai dari tahap awal berupa pembuatan jadwal faktual kegiatan, perancangan dan pembelian bahan, sampai dengan tahap pembuatan rangka kincir angin dan kincir anginnya, melakukan perakitan semua komponen pelengkap seperti kincir angin, pompa dan bantalan kincir (rakit kincir atau anjungan) semua sesuai dengan rancangan yang dibuat yaitu tinggi kincir angin beserta rakitnya $270 \mathrm{~cm}$ dari permukaan tambak garam dengan luasan kincir angin $100 \times 98 \mathrm{~cm}$.

Hasil monitoring yang dilakukan setelah pompa terpasang dapat diketahui bahwa pompa dapat bekerja dengan baik sesuai harapan yaitu diperoleh 50 - 70 putaran kincir angin pada kecepatan angin normal 3 sampai dengan $7 \mathrm{~km} /$ menit sehingga diperoleh daya isap pompa dalam satu menit antara 10 - 14 kali, dapat mengalirkan air ke tambak garam dengan kemampuan setara dengan 19,625 liter sampai dengan 27,475 Liter air/menit. 


\section{DAFTAR PUSTAKA}

Daryanto., Y. 2007. Kajian Potensi angin Untuk Pembangkit Listrik Tenaga Bayu. BALAI PPTAGG-UPT-LAGG. Yogyakarta. http:// mst.gadjahmada.edu/dl/Kincir_Angin.pdf (diakses tanggal 12-04-2008).

Nahib .I., Yatin S, Yosef P, dan Syahrul Arief. 2012, Potensi Garam di Kupang : Sumberdaya yang Melimpah \& Tinggal Ambil Badan Koordinasi Survei dan Pemetaan Nasional. Jakarta.
Suwoto, dkk., 2002. Perekayasaan Sistem Kincir Angin Untuk Lahan Kritis di Pantai Pandansimo, Kabupaten Bantul DIY. Lokakarya Hasil IPTEK Nuklir. P2SRMBatan. (www.energy.iastate.edu) diakses tanggal 12-04-2008).

Tempo, Selasa, 18 September 2012. NTT Kekurangan Garam Hingga 10 Ribu Ton. 